\title{
Entrepreneurship Education Through Mobile Augmented Reality for Introducing SMEs in Higher Education
}

https://doi.org/10.3991/ijim.v15i03.18437

\author{
Robinson Situmorang ${ }^{\bowtie}$, Cecep Kustandi, Santi Maudiarti, \\ Retno Widyaningrum, Diana Ariani \\ Universitas Negeri Jakarta, Jakarta, Indonesia \\ rsitumorang@unj.ac.id
}

\begin{abstract}
Entrepreneurship Education through Augmented Reality can give advantages in the learning process. This article aims to assess the development of Mobile Augmented Reality to introduce SMEs to college students. In the indication process, we used a mixed exploratory method. The needs of students in the learning process are carried out through a qualitative approach with interviews. We identify the effectiveness of Mobile Augmented Reality through a quantitative approach, namely surveys and tests. Our findings show that $77 \%$ of students give an opinion that Mobile Augmented Reality is effective. Also, student learning outcomes show an increase at posttest. Our research confirms that students' experience as users is essential for adopting Mobile Augmented Reality in the learning process.
\end{abstract}

Keywords-Mobile Augmented Reality, entrepreneurship education

\section{Introduction}

\subsection{Entrepreneurship education using technology}

The rapid development of technology and information in various aspects of life, including in entrepreneurship education, is an effort to bridge the present and the future by introducing reforms that tend to pursue efficiency and effectiveness [1]. Higher education has a role in developing entrepreneurship education to increase student interest in entrepreneurship [2]. Information and communication technology's advantages are speed to obtain information and facilitate learning to be more attractive, visual, and interactive [3]. Also, students can improve their thinking skills and gain broader, more in-depth insights [4]. One way that can be done to create new entrepreneurs is to motivate students through entrepreneurship education [5]. Entrepreneurial development can be directed to the technology field by creating more innovative products [6]. The change in the economy from resource-based to knowledge-based presents technology entrepreneurs who rely on innovation to create a knowledge-based economy [7]. In the Netherlands, higher education plays a role as an intermediary for economic knowledge and 
interaction with SMEs [8]. Besides, tertiary institutions play a role in producing superior human resources and influencing students' technological entrepreneurship abilities on individual innovation behavior with industrial revolution 4.0 [9].

Based on the research results by Boocock, Frank, and Warren [10], to encourage universities to teach entrepreneurship to students, the need for technology transfer to create economic value from technological change. Therefore, this research develops entrepreneurship education through Augmented Reality-based SMEs and Digital Flashcards. According to Thomas, Narayanan, and Ramanathan [11], SMEs' technology and industry clusters play a significant role in the economy. On the other side, Park et al. [12] show technology and market dynamism have a mediating-moderating effect on SMEs' business per-performance. Yun, Won, and Park [13] explained user innovation, customer innovation, and collective intelligence are open sources of innovation across the boundaries of knowledge and Technology. Therefore, the development of media science in educational Technology provides various kinds of learning media, both online and offline, to help SMEs and the creative industry foster creativity in marketing products. In Korea, Technology based on SMEs plays a mediating role in learning transfer [14].

Therefore, information and promotion media are needed to increase public interest. One of them is introducing SMEs to students. This promotional strategy is intended to make SMEs a strong and independent business in the national economy [15]. When developing instructional engineering, high imagination is required. Imagination is needed to imagine objects from SME products [16]. It is necessary to manufacture Technology that is used during the learning process. Therefore, researchers use one Technology that can be used to help students increase their imagination through Augmented Reality[17]. Augmented Reality (AR) technology is a combination between virtual objects and real objects naturally through a computeristic process as if it looks like it is in front of the user[18] provides an overview to the user about the merging of the real world with the virtual world seen from the same place[19]. Augmented Reality has three characteristics, namely interactive (increasing user interaction and perception with the real world), according to real-time, and in the form of 3 dimensions [20].

\section{Entrepreneurship Education and Augmented Reality}

Based on the research results of Yaoyuneyong, Foster, and Flynn [21], Augmented Reality is a necessity for the economic sector as it was developed as online visual merchandising in the Marketing study program in the United States. Also, the potential of Augmented Reality has a positive impact on higher education. According to Bower et al. [22], Augmented Reality is a technology that can contribute to developing students' higher-order thinking skills. Interestingly, the definition of Augmented Reality differs between researchers in computer science and educational technology. However, in general, Augmented Reality provides accurate registration of virtual and real three-dimensional objects [23]. So Elfeky and Elbyaly [24] explain that Augmented Reality is a technology that utilizes mobile and allows students to interact with digital information embedded in the physical environment. 
On the other hand, Radosavljevic, Radosavljevic, and Grgurovic [20] showed that Augmented Reality could shorten task realization through mobile learning. Therefore, the emergence of Technology in entrepreneurship education is carried out to improve and enhance the human learning process [25]. Also, Augmented Reality technology can be run via a Smartphone [26]. It is because smartphones are a device that is currently popular and has high mobility [27]. Thus, smartphones become tools that can help the learning process in the classroom [28]. Therefore, it can be said that the learning process through mobile phones can improve the student learning process [29]. According to Vidal et al. [30], creating Augmented Reality on Android-based Mobile Devices requires hardware support and tools as needed. Saudagar and Mohammad [31] show that Augmented Reality developed through Android is more efficient, accurate, and fast to use. Augmented Reality is proliferating using mobile devices in the educational process [32], [33], [34]. It is because mobile devices are a robust platform to support Augmented Reality development. After all, they have good digital cameras and navigator [35].

Improving education quality as a means of learning is highly prioritized because education can foster superior and quality human resources, especially in entrepreneurship education [36]. According to Kumaran et al. [37], Technology's effect is mobile devices on digital economy prospects. Grzegorczyk et al. [38] explained that Augmented Reality makes it easier for individuals to understand the product being introduced. Based on Jones et al. [39], Technology is related to a set of tools that help SMEs work with information processing.

Augmented Reality allows users to interact with the environment either based on virtual objects [40]. Virtual objects display information that is indirectly received by users with their senses. Making Reality appropriate as a tool for user perception and interaction with the real world [41].

\section{Methodology}

The research method used is the exploratory mixed method. To develop measurements related to the effectiveness of Augmented Reality, researchers explored data through a qualitative approach and analysis using a quantitative approach. Exploratory use is considered suitable for conducting theory testing but also potential theory development.

\subsection{Qualitative approach}

Participating students were selected by purposive sampling technique based on the entrepreneurship education subject being taught. The selected students must meet the criteria as active students who get entrepreneurship education courses and have Android smartphones. Interviews were conducted using a direct interview method using a semistructured questionnaire. Interviews were conducted after the entrepreneurship education course took place. We conducted interviews with 20 students from the educational technology study program and 20 students from the Jakarta State University civic 
education study program. This study analyzed students' responses to understanding related to learning design, Augmented Reality, Entrepreneurship Education, and SMEs. Besides, we also asked about the needs of students in the learning process of entrepreneurship education.

\subsection{Quantitative approach}

Based on the qualitative study findings, we decided to continue a quantitative study of the attractiveness of Augmented Reality for students and lecturers. Therefore, we developed the Mobile Augmented Reality design using the Vuforia Software Development Kit as the software platform. Vuforia allows developers to develop an interactive 3D experience and supports various 2D and 3D target types, including Image Targets (Markerless), 3D Multi-target configurations, and Marker Frame shapes and has the additional feature of local occlusion detection using virtual icons. Mobile Augmented Reality aims to introduce SMEs to students through entrepreneurship education. So, to make it easier for lecturers to provide material, we developed mobile Augmented Reality by making markers to take pictures of SME objects in the Cirebon area, West Java. The SMEs selected according to the research needs, namely Fashion, Art, Food, and Beverages. The SME object's image is then used as image tracking, and the resulting image is edited as an image tracker. After the application was developed, the researcher conducted a validity test with educational technology experts and entrepreneurship education. Furthermore, construct validity was performed by asking for expert judgment. Then the results were corrected during field trials. After obtaining the results of field trials, the validity of each type of instrument is calculated. In this study, the formula for product-moment with rough numbers is used, namely [42]:

$$
\begin{gathered}
r_{x y}=\frac{N \sum X Y-\left(\sum X\right)\left(\sum Y\right)}{\sqrt{\left\{N \sum X^{2}-\left(\sum X\right)^{2}\right\}\left\{N \sum Y^{2}-\left(\sum Y\right)^{2}\right\}}} \\
r_{11}=\left(\frac{n}{(n-1)}\right)\left(\frac{s_{t}^{2}-\Sigma p_{i} q_{i}}{s_{t}^{2}}\right)
\end{gathered}
$$

If greater than or equal to $0.361\left(r_{x y} \geq 0.361\right)$, the question number is said to be valid. In contrast, if it is less than $0.361\left(r_{x y} \leq 0.361\right)$, the question number is said to be invalid on formula (1). To calculate the test instrument's reliability, the writer used the Kuder and Richardson formula (2). Kuder and Richardson argue that "the way to determine the reliability of the test is more appropriate if it is carried out directly on the test items concerned [43]. Researchers observed the respondents' dynamics through quantitative studies to see the effectiveness of the developed Mobile Augmented Reality. Through a reliable instrument. Also, for non-test instruments using a rating scale. If the results of r11 are obtained in the range of $0.800-1,000$, it means that the correlation is very high, $0.600-0.799$ the correlation is high, $0.400-0.599$ the correlation is sufficient, and if the chain is $0.200-0.399$, the correlation is low. In the application trial process, we used purposive sampling to see the effectiveness of Mobile Augmented Reality with student learning outcomes related to SMEs' entrepreneurship education. Characteristics 
The selected students were 50 active students of civic education study programs and 50 technology education students. Generation Y Jakarta State University aged 19-20 years is further open to testing, purchasing, and using new technology. So that purchasing power increases based on Technology. The following questions were asked in the survey: 1. Have you heard of Augmented Reality? 2. Have you used Augmented Reality 3. Where did you find Augmented Reality? 3. Which application functions are most interesting to you? 4. Is the use of Mobile Augmented Reality effective in the SMEs' learning process in Entrepreneurship Education? 6. Would you recommend this application for college students?

The judgment expert's questionnaire was compiled using a Likert scale with a range of values 1-5 for negative-positive answers. Meanwhile, the questionnaire for student trials was compiled using a Likert scale. When researchers conducted an empirical feasibility test, there were some data in the form of numbers that came from the survey and test results. Two types of tests are used, namely pretest and posttest, with the following interval values:

Table 1. Score Interval

\begin{tabular}{|c|l|}
\hline Scores & \multicolumn{1}{|c|}{ Criteria for Interpretation } \\
\hline $80-100$ & Excellent \\
\hline $66-79$ & Good \\
\hline $56-65$ & Fair \\
\hline $40-55$ & Poor \\
\hline $0-39$ & Very Poor \\
\hline
\end{tabular}

\section{$4 \quad$ Results and Discussion}

\subsection{Qualitative case study}

At the qualitative stage, to maintain our research's ethics, we disguised the names of informants. The results of interviews conducted by researchers related to understanding learning design are generally summarized in the table as follows:

Table 2. Need Analysis of Students

\begin{tabular}{|l|c|l|}
\hline Participant & Aged & \multicolumn{1}{c|}{ Statement } \\
\hline Maya & 20 & $\begin{array}{l}\text { "Learning design leads to the preparation of communication technology media to as- } \\
\text { sist lecturers in transferring knowledge effectively to students. I often use the inter- } \\
\text { net as a learning support facility. Moreover, the learning design course is also criti- } \\
\text { cal to implement." }\end{array}$ \\
\hline Anugerah & 20 & $\begin{array}{l}\text { "Learning design courses cannot be separated from technology so that in the learn- } \\
\text { ing process, students often use the internet to find learning resources." }\end{array}$ \\
\hline Sheila & 19 & $\begin{array}{l}\text { "instructional design discusses various research and theories about strategies and the } \\
\text { learning development process and its implementation. Lecturers direct students to } \\
\text { use the internet and technology in the learning process actively." }\end{array}$ \\
\hline
\end{tabular}


Based on the statements in Table 2 shows that students understand the learning design. The intensity of using the internet and Technology is an obligation that must be done by students to become a learning resource. It is just that, in general, questions related to Augmented Reality show interest for students. However, there are no students who have used Augmented Reality in the learning process. Thus, the understanding of SMEs which are summarized in the table as follows:

Table 3. Need Analysis of Students

\begin{tabular}{|l|c|l|}
\hline Participant & Aged & \multicolumn{1}{|c|}{ Statement } \\
\hline Rana & 21 & $\begin{array}{l}\text { "The SMEs that I know are only a few. Because quality is sometimes not good. } \\
\text { Moreover, rarely know the location. When traveling out of town, only buy souvenirs } \\
\text { and even those that are often visited by visitors." }\end{array}$ \\
\hline Deri & 19 & $\begin{array}{l}\text { "There are many SMEs in Indonesia. However, it is difficult to find the location be- } \\
\text { cause it is not on the Map. Then the product is also less attractive. Although there } \\
\text { are several products from well-known SMEs." }\end{array}$ \\
\hline Aliyah & 20 & $\begin{array}{l}\text { "SMEs adalah Small Medium Entrepreneurship biasanya menjual produk buatan lo- } \\
\text { kal." }\end{array}$ \\
\hline
\end{tabular}

Table 3 shows that, in general, students understand SMEs; it is just that they have difficulty knowing SMEs' products because they are not used to buying the products. Besides, our respondents found the advantages of entrepreneurship education through mobile-based Technology. Entrepreneurship education provides an understanding of the process of becoming an entrepreneur. The lecturers we interviewed explained that the comparison of technology-based learning media was much more effective than traditional. The average answer to the question indicates this Is learning based on mobile devices much more effective than traditional (1-5)? Is 4.20 with the answers: $3 ; 4 ; 4 ; 5$; 5 .

\subsection{Design of mobile augmented reality for entrepreneurship education}

The qualitative analysis results were used as a research need to design a mobile Augmented Reality. The right method for detecting real objects is the markerless method for recognizing objects. In Android, computer vision techniques are using to detect real objects. One Augmented Reality technology provider uses these techniques in Qualcomm's mobile device to detect objects using the markerless method. This method allows us to detect real objects directly without using markers. With the tools provided by Qual-comm for the development of mobile device-based Augmented Reality, it is easier for developers to create markerless applications. Marker creation is done by taking pictures of the SMEs object. The edited image was uploading to the Qualcomm Developer website. We provide solutions to innovate entrepreneurial education by building a mobile Augmented Reality architecture. Architectural characteristics in Augmented Reality technology have three basic characteristics: the combination of the real and virtual worlds, real-time interactions, and the last characteristic is the object's shape in a 3-dimensional or 3D model. The form of contextual data in this Augmented Reality system can be location data, audio, video, and 3D model data. Before conducting trials 
on students, we validated the expert's judgment regarding the Mobile Augmented Reality trial questionnaire as follows:

Table 4. Need Analysis of Students

\begin{tabular}{|c|c|c|c|}
\hline No & Significance Level & Categories & Total \\
\hline 1 & $\mathrm{r}>0,361$ & Valid & 20 \\
\hline 2 & $\mathrm{r}<0,361$ & Invalid & 0 \\
\hline
\end{tabular}

Based on the data analysis of the learning style questionnaire's validity test, the analysis results show that the instrument is valid if the value is $>0.361$. So, of the 20 items in the questionnaire statement, all are known to be valid. Meanwhile, based on the instrument items' analysis, the test reliability coefficient is 0.635 , so it can be said that the test instrument is reliable. After testing the judgment expert's validity, we tested the students by giving them a Mobile Augmented Reality product package. The smartphone used by the participant has the "Knowing SMEs" application available. Fig.1. shows the process of using the application carried out by students.

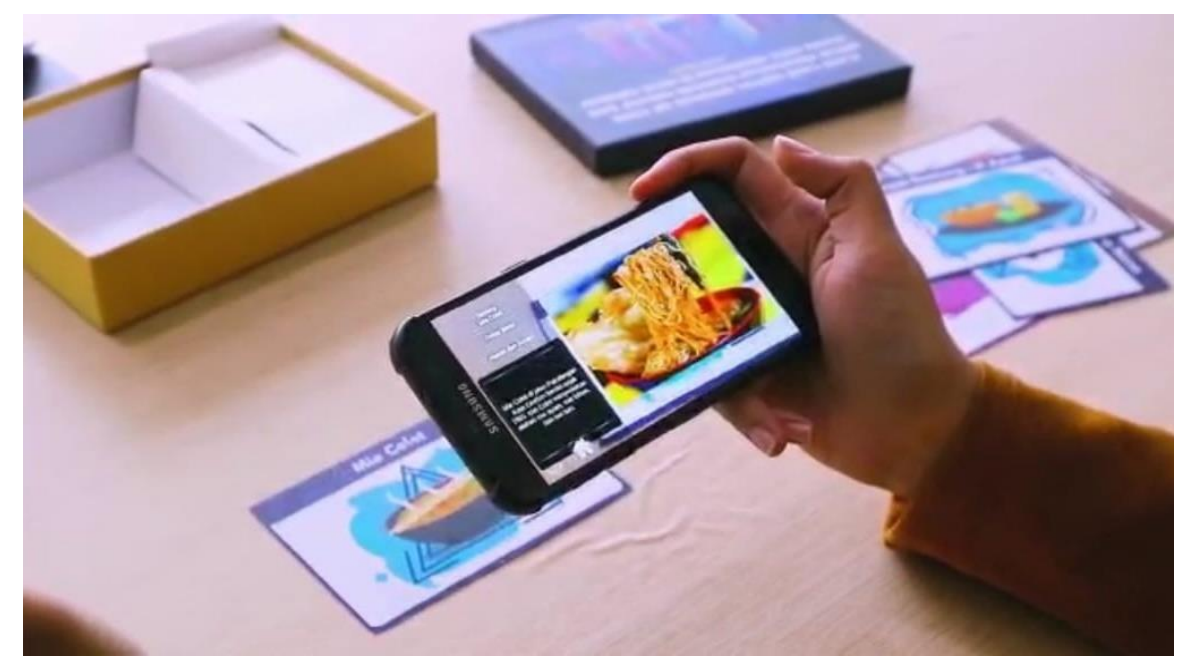

Fig. 1. Mobile Augmented Reality

The survey results from the Mobile Augmented Reality application for Jakarta State University students are presented in an aggregate form. The first question aims to find out whether students have heard of Augmented Reality. As much as $45 \%$ of the Citizenship Education study program answered yes, while 55\% of students of the Technology Education study program had never heard of it. $75 \%$ of students of the Citizenship Education study program have never used Augmented Reality. However, 55\% of students of educational technology study programs have used Augmented Reality. 57\% of students have discovered this Technology through the internet, and $43 \%$ of that in education. Table 5 shows the answers to questions about the most interesting functions of the Mobile Augmented Reality application. While Fig.3. shows the effectiveness of 
Mobile Augmented Reality on the SMEs' learning process. The next question tests whether students will recommend the Mobile Augmented Reality application (Likert scale. ' 1 ' shows that they think they will not recommend the Mobile Augmented Reality application, while '5' will recommend the Mobile Augmented Reality application.

Table 5. The Most Interesting Functions of The Mobile Augmented Reality

\begin{tabular}{|l|c|}
\hline \multicolumn{1}{|c|}{ Legend } & Percentage \\
\hline Displaying information and characteristics of SMEs & $77 \%$ \\
\hline They are displaying information about SME products with the route, street names, etc & $45 \%$ \\
\hline Watching the virtual of various products available on SMEs through application & $55 \%$ \\
\hline Interactive advertisement & $24 \%$ \\
\hline View product SMEs by scanning flashcards & $75 \%$ \\
\hline
\end{tabular}

Table 6. Expressing the Opinion about Mobile Augmented Reality Effectiveness

\begin{tabular}{|c|l|c|}
\hline No & \multicolumn{1}{|c|}{ Expressing } & Percentage \\
\hline 1 & Effective & $77 \%$ \\
\hline 2 & Uneffective & $23 \%$ \\
\hline \multicolumn{2}{|c|}{ Total } & $100 \%$ \\
\hline
\end{tabular}

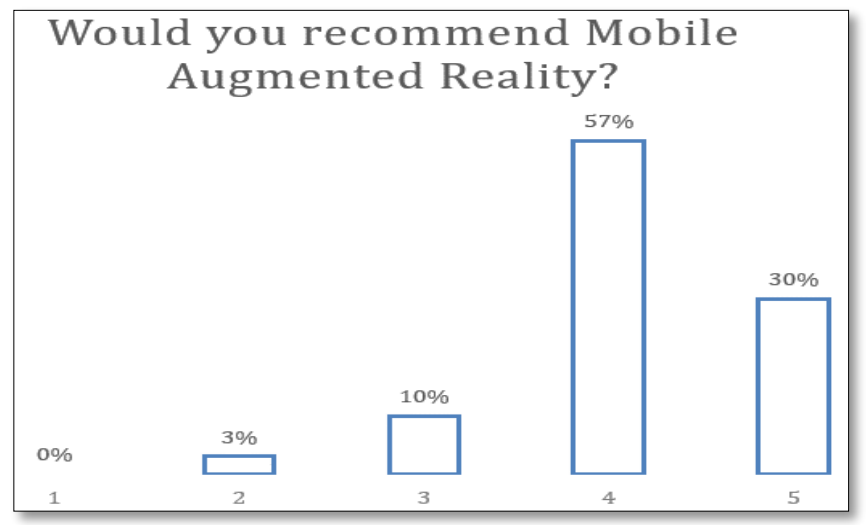

Fig. 2. The header image of online-journals.org

After conducting a survey, to see the effectiveness of using Mobile Augmented Reality, we conducted a pretest and posttest related to SMEs material in entrepreneurship education. The tests given to students are related to entrepreneurship, entrepreneurial characteristics, SMEs' definition, SMEs' classification, SMEs' criteria, and SMEs' examples. 
Paper-Entrepreneurship Education Through Mobile Augmented Reality for Introducing SMEs...

Table 7. The Results of Pretest and Post-Test

\begin{tabular}{|c|c|c|c|c|c|}
\hline \multirow{2}{*}{ Scores Interval } & \multirow{2}{*}{ Categories } & \multicolumn{2}{|c|}{ Pretest } & \multicolumn{2}{c|}{ Post-Test } \\
\cline { 3 - 6 } & & Frequency & $\%$ & Frequency & $\%$ \\
\hline $80-100$ & Excellent & 0 & $0 \%$ & 5 & $10 \%$ \\
\hline $66-79$ & Good & 5 & $10 \%$ & 25 & $50 \%$ \\
\hline $56-65$ & Fair & 20 & $40 \%$ & 15 & $30 \%$ \\
\hline $40-55$ & Poor & 15 & $30 \%$ & 4 & $8 \%$ \\
\hline $0-39$ & Very Poor & 10 & $20 \%$ & 1 & $2 \%$ \\
\hline \multicolumn{2}{r|}{ Total } & 50 & $100 \%$ & 50 & $100 \%$ \\
\hline
\end{tabular}

Based on the results of trials on students, it shows in line with the research of Hsu, Wenting, and Hughes [18] that the Mobile Augmented Reality developed improves student learning outcomes. Therefore, through Mo-bile Augmented Reality, it can increase the motivation to learn entrepreneurship education [44].

\subsection{Discussion}

The results of interviews with students related to student needs in the learning process of entrepreneurship education show that the diffusion theory of innovation affects the reinvention of useful learning media [45]. $77 \%$ of students give a useful opinion on the use of Mobile Augmented Reality. According to Chen [46], relevant factors influence students' perceived effectiveness and the expected value to be identified. In connection with creating a conducive atmosphere, the learning media has a significant role. According to Eze et al. [47], mobile technology media is a tool that helps the learning process of SMEs. Besides, students view that the Mobile Augmented Reality application's most exciting function lies in Displaying information and characteristics of SMEs [48]. These findings confirm Chen et al. [17] that Augmented Reality can increase learning motivation and provide students with contextual information about the learning environment. Therefore, science and technology development increasingly encourages renewal efforts in using technology results in the learning process [49], [50]. Although entrepreneurship education's initial goal is good, namely trying to introduce SMEs to students, if the right media do not support it, that goal will be challenging. Therefore, $57 \%$ of students indicated that they would recommend applying to students in other study programs. Also, previous studies highlighted the user experience of Augmented Reality only on the positive pleasure and effectiveness factors of using Augmented Reality [18], [19], [21], [22]. The results we get show that Mobile Augmented Reality can make learning activities more exciting and fun.

On the other hand, it can significantly improve student learning outcomes. The novelty of Augmented Reality in this study can be seen in the aspect of Watching the virtual of various products available on SMEs and the ease of accessing information due to its visual appeal. These factors have an impact on the emotional acceptance of Augmented Reality by students. As in the study of Elfeky and Elbyaly [24], our results emphasize Augmented Reality's effectiveness on students' abilities in the learning process. 


\section{Conclusion}

Augmented Reality technology applications are currently being used in various fields and will experience significant developments in the future. Responding to the research gap, we aim to offer Augmented Reality developments in entrepreneurship education. The results showed that Augmented Reality could increase the learning process's effectiveness, which is the basis for table 7. This study's results can provide information for future researchers that Augmented Reality is fascinating to be applied to the learning process of entrepreneurship education. It has a significant impact on the results of students' pretest and posttest related to SMEs material. However, this study has several limitations and is needed to conduct further research. This research concentrates mainly on Indonesia. Therefore, we are reluctant to state that this study's results can be applied in other countries. It is due to differences in entrepreneurship education curricula in various countries. So that these differences will be beneficial for carrying out similar studies in different countries. Besides, to study the effect of differences in entrepreneurship education curricula on student preferences for Augmented Reality.

\section{References}

[1] S. Papadakis, M. Kalogiannakis, V. Orfanakis, and N. Zaranis, "The Appropriateness of Scratch and App Inventor as Educational Environments for Teaching Introductory Programming in Primary and Secondary Education." International Journal of Web-Based Learning and Teaching Technologies (IJWLTT), 12(4), 58-77, 2017. https://doi.org/10.4018/ijwltt. 2017100106

[2] T. Davey, P. Hannon, and A. Penaluna, "Entrepreneurship education and the role of universities in entrepreneurship: Introduction to the special issue," Ind. High. Educ., vol. 30, no. 3, pp. 171-182, 2016. https://doi.org/10.1177/0950422216656699

[3] M. Kalogiannakis and S. Papadakis, "Pre-service kindergarten teachers' acceptance of 'ScratchJr' as a tool for learning and teaching computational thinking and Science education," in the 12th Conference of the European Science Education Research Association (ESERA), 2017, pp. 21-25.

[4] M. Kalogiannakis, G.M. Nirgianaki, and S. Papadakis, "Teaching Magnetism to Preschool Children: The Effectiveness of Picture Story Reading." Early Childhood Educ J 46, 535546, 2018. https://doi.org/10.1007/s10643-017-0884-4

[5] K. Berglund, U. Hytti, and K. Verduijn, "Unsettling Entrepreneurship Education," Entrep. Educ. Pedagog., vol. 3, no. 3, pp. 208-213, 2020. https://doi.org/10.1177/251512742092 1480

[6] S. Nambisan, "Digital Entrepreneurship: Toward a Digital Technology Perspective of Entrepreneurship," Entrep. Theory Pract., vol. 41, no. 6, pp., 1029-1055, 2017. https://doi.org/ 10.1111/etap. 12254

[7] H. Löfsten, "New technology-based firms and their survival: The importance of business networks, and entrepreneurial business behaviour and competition," Local Econ., vol. 31, no. 3, pp. 393-409, 2016. https://doi.org/10.1177/0269094216637334

[8] H. Delfmann and S. Koster, "Knowledge Transfer between SMEs and Higher Education Institutions: Differences between Universities and Colleges of Higher Education in the Netherlands," Ind. High. Educ., vol. 26, no. 1, pp. 31-42, 2012. https://doi.org/10.5367/ihe. $\underline{2012.0079}$ 
[9] O. (Lola) Dada and H. Fogg, "Organizational learning, entrepreneurial orientation, and the role of university engagement in SMEs," Int. Small Bus. J. Res. Entrep., vol. 34, no. 1, pp. 86-104, 2014. https://doi.org/10.1177/0266242614542852

[10] G. Boocock, R. Frank, and L. Warren, "Technology-Based Entrepreneurship Education: Meeting Educational and Business Objectives," Int. J. Entrep. Innov., vol. 10, no. 1, pp. 4353, 2009. https://doi.org/10.5367/000000009787414226

[11] R. M. Thomas, K. Narayanan, and A. Ramanathan, "A Comparative Study of Technology and Industry Clusters of SMEs in India," Sci. Technol. Soc., vol. 17, no. 3, pp. 409-430, 2012. https://doi.org/10.1177/097172181201700304

[12] H. Park et al., "Effect of Technology and Market Dynamism on the Business Performances of SMEs by Supporting Services," Sci. Technol. Soc., vol. 24, no. 1, pp. 144-160, 2019.

[13] J. H. J. Yun, D. K. Won, and K. Park, "Dynamics from open innovation to evolutionary change," J. Open Innov. Technol. Mark. Complex., vol. 2, no. 2, 2016.

[14] S. Sung, J. Rhee, and J. Yoon, "Learning Organisation Activities and Innovativeness of Tech-based SMEs within Korean Technoparks: The Mediating Role of Learning Transfer," Sci. Technol. Soc., vol. 21, no. 3, pp. 410-434, 2016. https://doi.org/10.1177/097172181 6666120

[15] T. Tambunan, "The Role of Government in Technology Transfer to SME Clusters in Indonesia," South East Asia Res., vol. 15, no. 3, pp. 385-406, 2007. https://doi.org/10.5367/ 000000007782717768

[16] M. G. O. Ogola, D. Sikalieh, and T. K. Linge, "The Influence of Idealized Influence Leadership Behavior on Employee Performance in Small and Medium Enterprises in Kenya," Eur. Int. J. Sci. Technol., vol. 6, no. 3, pp. 163-173, 2017.

[17] D. R. Chen, M. Y. Chen, T. C. Huang, and W. P. Hsu, "Developing a mobile learning system in Augmented Reality context," Int. J. Distrib. Sens. Networks, vol. 9, no. 12, 2013.

[18] H. P. Hsu, Z. Wenting, and J. E. Hughes, "Developing Elementary Students' Digital Literacy Through Augmented Reality Creation: Insights From a Longfrominal Analysis of Questionnaires, Interviews, and Projects," J. Educ. Comput. Res., vol. 57, no. 6, pp., 1400-1435, 2019. https://doi.org/10.1177/0735633118794515

[19] T. Gjøsæter, "Affordances in mobile Augmented Reality applications," Int. J. Interact. Mob. Technol., vol. 8, no. 4, pp. 45-55, 2014. https://doi.org/10.3991/ijim.v8i4.4051

[20] S. Radosavljevic, V. Radosavljevic, and B. Grgurovic, "The potential of implementing Augmented Reality into vocational higher education through mobile learning," Interact. Learn. Environ., vol. 28, no. 4, pp. 404-418, 2020. https://doi.org/10.1080/10494820.2018.1528 $\underline{286}$

[21] G. Yaoyuneyong, J. K. Foster, and L. R. Flynn, "Factors impacting the efficacy of Augmented Reality virtual dressing room technology as a tool for online visual merchandising," J. Glob. Fash. Mark., vol. 5, no. 4, pp. 283-296, 2014. https://doi.org/10.1080/20932685. 2014.926129

[22] M. Bower, C. Howe, N. McCredie, A. Robinson, and D. Grover, "Augmented Reality in education - cases, places and potentials," EMI. Educ. Media Int., vol. 51, no. 1, pp. 1-15, 2014. https://doi.org/10.1080/09523987.2014.889400

[23] G. Koutromanos, A. Sofos, and L. Avraamidou, "The use of Augmented Reality games in education: a review of the literature," EMI. Educ. Media Int., vol. 52, no. 4, pp. 253-271, 2015. https://doi.org/10.1080/09523987.2015.1125988

[24] A. I. M. Elfeky and M. Y. H. Elbyaly, "Developing skills of fashion design by Augmented Reality technology in higher education," Interact. Learn. Environ., 2018. https://doi.org/10. 1080/10494820.2018.1558259

[25] S. Papadakis, "Evaluating pre-service teachers' acceptance of mobile devices with regards to their age and gender: A case study in Greece," Int. J. Mob. Learn. Organ., vol. 12, no. 4, pp. 336-352, 2018. https://doi.org/10.1504/ijmlo.2018.10013372 
[26] S. Ahn, H. Ko, and B. Yoo, "Webizing mobile Augmented Reality content," New Rev. Hypermedia Multimed., vol. 20, no. 1, pp. 79-100, 2014. https://doi.org/10.1080/13614568. 2013.857727

[27] S. Papadakis and M. Kalogiannakis, "Evaluating a course for teaching introductory programming with Scratch to pre-service kindergarten teachers," Int. J. Technol. Enhanc. Learn., vol. 11, no. 3, pp. 231-246, 2019. https://doi.org/10.1504/ijtel.2019.10020447

[28] S. Papadakis, "Evaluating a game-development approach to teach introductory programming concepts in secondary education," Int. J. Technol. Enhanc. Learn., vol. 12, no. 2, pp. 127-145, 2020. https://doi.org/10.1504/ijtel.2020.106282

[29] S. Papadakis, N. Zaranis, and M. Kalogiannakis, "Parental involvement and attitudes towards young Greek children's mobile usage" International Journal of Child-Computer Interaction, 22, 100144, 2019. https://doi.org/10.1016/j.ijcci.2019.100144

[30] E. C. E. Vidal, J. F. Ty, N. R. Caluya, and M. M. T. Rodrigo, "MAGIS: mobile augmentedreality games for instructional support," Interact. Learn. Environ., vol. 0, no. 0, pp. 1-13, 2018. https://doi.org/10.1080/10494820.2018.1504305

[31] A. K. J. Saudagar and H. Mohammad, "Augmented Reality mobile application for arabic text extraction, recognition and translation," J. Stat. Manag. Syst., vol. 21, no. 4, pp. 617629, 2018. https://doi.org/10.1080/09720510.2018.1466968

[32] M. C. tom Dieck and T. Jung, "A theoretical model of mobile Augmented Reality acceptance in urban heritage tourism," Curr. Issues Tour., vol. 21, no. 2, pp. 154-174, 2018. https://doi.org/10.1080/13683500.2015.1070801

[33] W. H. Lee and H. K. Lee, "The usability attributes and evaluation measurements of mobile media AR (Augmented Reality)," Cogent Arts Humanit., vol. 3, no. 1, pp. 1-16, 2016. https://doi.org/10.1080/23311983.2016.1241171

[34] H. Y. Chang, Y. S. Hsu, H. K. Wu, and C. C. Tsai, "Students' development of socio-scientific reasoning in a mobile Augmented Reality learning environment," Int. J. Sci. Educ., vol. 40, no. 12, pp. 1410-1431, 2018. https://doi.org/10.1080/09500693.2018.1480075

[35] S. Papadakis, M. Kalogiannakis, E. Sifaki, and N. Vidakis, "Evaluating Moodle use via Smart Mobile Phones. A case study in a Greek University," EAI Endorsed Trans. Creat. Technol., vol. 5, no. 16, 2018. https://doi.org/10.4108/eai.10-4-2018.156382

[36] B. A. Friedman, "Globalization implications for human resource management roles," Empl. Responsib. Rights J., vol. 19, no. 3, pp. 157-171, 2007.

[37] V. V. Kumaran, S. S. Nathan, A. Hussain, and N. L. Hashim, "Mobile banking usability evaluation among deaf: A review on financial technology and digital economy prospects," Int. J. Interact. Mob. Technol., vol. 13, no. 11, pp. 24-33, 2019. https://doi.org/10.3991/ ijim.v13i11.11512

[38] T. Grzegorczyk, R. Sliwinski, and J. Kaczmarek, "Attractiveness of Augmented Reality to consumers," Technol. Anal. Strateg. Manag., vol. 31, no. 11, pp. 1257-1269, 2019. https://doi.org/10.1080/09537325.2019.1603368

[39] R. Jones, M. Suoranta, and J. Rowley, "Strategic network marketing in technology SMEs," J. Mark. Manag., vol. 29, no. 5-6, pp. 671-697, 2013. https://doi.org/10.1080/0267257x. 2013.797920

[40] A. Carreon, S. J. Smith, and A. Rowland, "Augmented Reality: Creating and Implementing Digital Classroom Supports,” J. Spec. Educ. Technol., vol. 35, no. 2, pp. 109-115, 2020. https://doi.org/10.1177/0162643419882423

[41] B. Carl, M. Bopp, B. Saß, M. Pojskic, B. Voellger, and C. Nimsky, "Spine Surgery Supported by Augmented Reality," Glob. Spine J., vol. 10, no. 2_suppl, pp. 41S-55S, 2020. https://doi.org/10.1177/2192568219868217

[42] S. E. P. Widoyoko, Teknik Penyusunan Intrumen Penelitian. Yogyakarta: Pustaka Belajar, 2015.

[43] A. Sudijono, Pengantar Statistik Pendidikan. Jakarta: Rajawali Press, 2009. 
[44] C. D. Kounavis, A. E. Kasimati, and E. D. Zamani, "Enhancing the tourism experience through mobile Augmented Reality: Challenges and prospects,” Int. J. Eng. Bus. Manag., vol. 4, no. 1, pp. 1-6, 2012. https://doi.org/10.5772/51644

[45] R. E. Rice and K. E. Pearce, "Divide and diffuse: Comparing digital divide and diffusion of innovations perspectives on mobile phone adoption," Mob. Media Commun., vol. 3, no. 3, pp. 401-424, 2015. https://doi.org/10.1177/2050157915590469

[46] T. L. Chen, "Exploring e-Learning Effectiveness Perceptions of Local Government Staff Based on the Diffusion of Innovations Model," Adm. Soc., vol. 46, no. 4, pp. 450-466, 2014. https://doi.org/10.1177/0095399713482313

[47] S. C. Eze, V. C. Chinedu-Eze, A. O. Bello, H. Inegbedion, T. Nwanji, and F. Asamu, "Mobile marketing technology adoption in service SMEs: a multi-perspective framework," J. Sci. Technol. Policy Manag., vol. 10, no. 3, pp. 569-596, 2019. https://doi.org/10.1108/ jstpm-11-2018-0105

[48] O.Aldalalah, Z. W. M. Ababneh, A. K. Bawaneh, and W.M.M. Alzubi, "Effect of Augmented Reality and Simulation on the Achievement of Mathematics and Visual Thinking Among Students,”Int. J. Emerg. Technol. Learn., vol. 14, no. 18, pp. 164-185, 2019. https:// doi.org/10.3991/ijet.v14i18.10748

[49] I. Lestari, A. Maksum, and C. Kustandi, "Mobile learning design models for State University of Jakarta, Indonesia," Int. J. Interact. Mob. Technol., vol. 13, no. 9, pp. 152-171, 2019. https://doi.org/10.3991/ijim.v13i09.10987

[50] F. Ozdamli, and C. Hursen, "An Emerging Technology: Augmented Reality to Promote Learning,'Int. J. Emerg. Technol. Learn., vol. 12, no. 11, pp. 121-137, 2017. https://doi. org/10.3991/ijet.v12i11.7354

\section{$7 \quad$ Authors}

Robinson Situmorang is a lecturer of Educational Technology, Faculty of Education Science at Universitas Negeri Jakarta.

Cecep Kustandi is a lecturer of Educational Technology, Faculty of Education Science, Universitas Negeri Jakarta. He is a member of research institutions and community service at Universitas Negeri Jakarta.

Santi Maudiarti is a lecturer of Educational Technology, Faculty of Education Science at Universitas Negeri Jakarta.

Retno Widyaningrum is a lecturer of Educational Technology, Faculty of Education Science at Universitas Negeri Jakarta

Diana Ariani is a lecturer of Educational Technology, Faculty of Education Science at Universitas Negeri Jakarta.

Article submitted 2020-09-11. Resubmitted 2020-12-03. Final acceptance 2020-12-04. Final version published as submitted by the authors. 